30 Hoen PW, Denollet J, de Jonge P, Whooley MA. Positive affect and survival in patients with stable coronary heart disease: findings from the Heart and Soul Study. J Clin Psychiatry 2013; 74: 716-22.

31 Wen CP, Wai JP, Tsai MK, Yang YC, Cheng TY, Lee MC, et al. Minimum amount of physical activity for reduced mortality and extended life expectancy: a prospective cohort study. Lancet 2011; 378: 1244-53.

32 Leventhal AM. Relations between anhedonia and physical activity. Am J Health Behav 2012; 36: 860-72.

33 American Psychiatric Association. Diagnostic and Statistical Manual of Mental Disorders (4th edn, text revision) (DSM-IV-TR). APA, 2000.

34 Hasler G, Drevets WC, Manji HK, Charney DS. Discovering endophenotypes for major depression. Neuropsychopharmacology 2004; 29: 1765-81.

35 Dockray S, Steptoe A. Positive affect and psychobiological processes. Neurosci Biobehav Rev 2010; 35: 69-75.

36 van der Feltz-Cornelis CM, Nuyen J, Stoop C, Chan J, Jacobson AM, Katon W, et al. Effect of interventions for major depressive disorder and significant depressive symptoms in patients with diabetes mellitus: a systematic review and meta-analysis. Gen Hosp Psychiatry 2010; 32: 380-95.
37 Thombs BD, Ziegelstein RC. Diabetes, depression, and death: a randomized controlled trial of a depression treatment program for older adults based in primary care (PROSPECT): response to Bogner et al. Diabetes Care 2008; 31: e54; author reply e5.

38 Pozuelo L, Tesar G, Zhang J, Penn M, Franco K, Jiang W. Depression and heart disease: what do we know, and where are we headed? Cleve Clin J Med 2009; 76: 59-70.

39 Sturmey P. Behavioral activation is an evidence-based treatment for depression. Behav Modif 2009; 33: 818-29.

40 Lejuez CW, Hopko DR, Acierno R, Daughters SB, Pagoto SL. Ten year revision of the brief behavioral activation treatment for depression: revised treatment manual. Behav Modif 2011; 35: 111-61.

41 de Miranda Azevedo R, Roest AM, Hoen PW, de Jonge P. Cognitive/affective and somatic/affective symptoms of depression in patients with heart disease and their association with cardiovascular prognosis: a meta-analysis. Psychol Med 2014; 44: 2689-703.

\title{
Keeping the Woolf from the Door
}

\section{Jo McFarlane}

Are you afraid of Virginia Woolf?

her crazy ramblings in the moonlit hours,

the tidal toss of mania and darkness looming like a shroud

Who's afraid of going mad?

Suicidal paranoia in a job rejection,

being sectioned for a first blow to your shadow,

coming 'home' to hospital, a four year stretch

of queuing up for liquid cosh, slippers tattered

from the endless pacing in your cubicle,

electrodes wired into your thoughts

Who's afraid?

Are you afraid of stripping like an onion,

weeping with the sting of dread

each time your name is called?

When I'm afraid

I write letters to Virginia Woolf

'What's the cleanest way to kill yourself?'

'Is it still crazy on the other side?'

She told me once there's no God in heaven,

now it's easier to pray

I wonder when my time will come

to tie a stone around my waist,

sink my sins into the river like Virginia

I'm not afraid. I'm not afraid. I'm not afraid.

Selected by Femi Oyebode. From Stigma \& Stones: Living with a Diagnosis of BPD, poems by Sally Fox \& Jo McFarlane (c) Jo McFarlane. Reprinted with permission.

Through their collection Stigma \& Stones, writers/performers/partners Sally Fox and Jo McFarlane seek to promote understanding, improve treatment and reduce the stigma of living with a diagnosis of BPD. 